\title{
Antimicrobial Peptide Brevinin-1RL1 from Frog Skin Secretion Induces Apoptosis and Necrosis of Tumor Cells
}

\author{
Xiaoman Ju ${ }^{1,2}$, Dongmei Fan 1,2 , Lingmei Kong 1,3, Qihong Yang 1,2, Yiying Zhu ${ }^{1}$, Shaohua Zhang 1,2, \\ Guifeng $\mathrm{Su}{ }^{1,2}$ and Yan $\mathrm{Li}^{1,3, *}$ \\ 1 State Key Laboratory of Phytochemistry and Plant Resources in West China, Kunming Institute of Botany, \\ Chinese Academy of Sciences, Kunming 650201, China; juxiaoman@mail.kib.ac.cn (X.J.); \\ fandongmei@mail.kib.ac.cn (D.F.); konglingmei@mail.kib.ac.cn (L.K.); yangqihong@mail.kib.ac.cn (Q.Y.); \\ zhuyiying@mail.kib.ac.cn (Y.Z.); zhangshaohua@mail.kib.ac.cn (S.Z.); suguifeng@mail.kib.ac.cn (G.S.) \\ 2 University of Chinese Academy of Sciences, Beijing 100049, China \\ 3 Yunnan Key Laboratory of Natural Medicinal Chemistry, Kunming Institute of Botany, \\ Chinese Academy of Sciences, Kunming 650201, China \\ * Correspondence: liyanb@mail.kib.ac.cn; Tel.: +86-871-652123031
}

Citation: Ju, X.; Fan, D.; Kong, L.; Yang, Q.; Zhu, Y.; Zhang, S.; Su, G.; Li, Y. Antimicrobial Peptide

Brevinin-1RL1 from Frog Skin Secretion Induces Apoptosis and Necrosis of Tumor Cells. Molecules 2021, 26, 2059. https://doi.org/ $10.3390 /$ molecules 26072059

Academic Editor: Jean-Marc Sabatier

Received: 4 March 2021

Accepted: 30 March 2021

Published: 3 April 2021

Publisher's Note: MDPI stays neutral with regard to jurisdictional claims in published maps and institutional affiliations.

Copyright: (C) 2021 by the authors Licensee MDPI, Basel, Switzerland. This article is an open access article distributed under the terms and conditions of the Creative Commons Attribution (CC BY) license (https:/ / creativecommons.org/licenses/by/ $4.0 /)$.

\begin{abstract}
Cancer has always been one of the most common malignant diseases in the world. Therefore, there is an urgent need to find potent agents with selective antitumor activity against cancer cells. It has been reported that antimicrobial peptides (AMPs) can selectively target tumor cells. In this study, we focused on the anti-tumor activity and mechanism of Brevinin-1RL1, a cationic $\alpha$-helical AMP isolated from frog Rana limnocharis skin secretions. We found that Brevinin-1RL1 preferentially inhibits tumor cells rather than non-tumor cells with slight hemolytic activity. Cell viability assay demonstrated the intermolecular disulfide bridge contributes to the inhibitory activity of the peptide as the antitumor activity was abolished when the disulfide bridge reduced. Further mechanism studies revealed that both necrosis and apoptosis are involved in Brevinin-1RL1 mediated tumor cells death. Moreover, Brevinin-1RL1 induced extrinsic and mitochondria intrinsic apoptosis is caspases dependent, as the pan-caspase inhibitor z-VAD-FMK rescued Brevinin-1RL1 induced tumor cell proliferative inhibition. Immunohistology staining showed Brevinin-1RL1 mainly aggregated on the surface of the tumor cells. These results together suggested that Brevinin-1RL1 preferentially converges on the cancer cells to trigger necrosis and caspase-dependent apoptosis and Brevinin-1RL1 could be considered as a pharmacological candidate for further development as anti-cancer agent.
\end{abstract}

Keywords: antimicrobial peptide; Brevinin-1RL1; apoptosis; necrosis; caspase; anticancer

\section{Introduction}

Although great progress has been made in the treatment of cancer in recent years [1-3], traditional therapies still have many defects and problems, such as widespread side effects due to non-adequate specificity for tumor cells and the tendency to develop multiple drug resistance, which greatly limit their therapeutic efficacy [4,5]. As a result, it is urgent to develop potent agents with selective antitumor activity against cancer cells.

Antimicrobial peptides (AMPs), also referred to as host defense peptides, have been isolated and characterized from a wide variety of organisms, such as microorganisms, insects, plants, birds, fish, amphibians and mammals, including humans, where they play an important role in the innate defense against microbial and viral invasions [6,7]. AMPs have a wide spectrum killing activity including Gram-positive and Gram-negative bacteria, fungi and protozoa without cytotoxicity towards normal mammal cells at the effective dose [8]. AMPs were initially discovered due to their role in the clearance of microorganisms $[9,10]$. As more natural-source peptides have been discovered, other biological activities of these peptides have been explored, such as anti-fungal, anti-viral and immune regulation, as well as anti-cancer activities [8,11]. According to the record, 
there are 3180 kinds of AMPs in the current Antimicrobial Peptide Database (APD), among which 237 peptides with anti-tumor activity are included.

Numerous naturally derived AMPs inhibit cancer cells mainly through plasma membrane disruption or non-membranolytic cytotoxicity [12]. AMPs, such as Defensin-peptides A, B [13], NK-2 [14] MPI-1 [15], Melittin [16], Pardaxin [17] and magainin 2 (MG2) [18], target and form pores on the cancer cell membranes to attenuate cancer cells, but Melittin is also toxic to non-cancer cells and has a powerful hemolytic activity. Non-membranolytic pathway mainly involves reactive oxygen species, DNA damage response [19], immune regulation [20], autophagy and apoptosis [21]. For example, FK-16 derived from LL-37 could induce tumor cell death by activating non-caspase-dependent apoptosis and autophagy [22]. LZ1, derived from the snake venom cathelicidin, could inhibit the activity of mTORC1 by targeting degradation of cell surface-expressed nucleolin to activate AMPK, thereby inhibiting the production of autophagic flux [23]. Hence, the current research on AMPs indicated that they might be potential drugs for future cancer treatment.

Brevinin-1RL1 is a member of the amphibian family of cationicAMPs originally isolated from Rana limnocharis composed of 24 amino acids and sharing an intra-molecular disulfide-bridged domain of 7-membered ring located at the C-terminus. It has been shown that Brevinin-1RL1 displays broadspectrum antibacterial activity [24]. In the present study, we disclosed that Brevinin-1RL1 preferential cytotoxicity for tumor cells to induce necrosis and caspase-dependent apoptosis to suppress tumor growth. Our study not only revealed the application of Brevinin-1RL1 as a potential candidate antitumor agent, but also further confirmed the possibility of AMPs as a promising anticancer drug.

\section{Results}

\subsection{Synthesis, Purification and Characterization of Peptides}

Brevinin-1RL1 is composed of 24 amino acids and it contains an intermolecular disulfide bridge consisting of seven amino acid residues at the C-terminus of the peptide. Table 1 shows the primary sequence and other biophysical parameters. The peptide was synthesized and purified by reverse-phase HPLC with the purity 95\% (Figure 1a, b). In addition, the HPLC chromatogram and MS of FITC labeled Brevinin-1RL1 are shown in Supplementary Materials Figure S1a,b, respectively. The helical wheel arrangement of Brevinin-1RL1 was produced using the HeliQuest website (http:/ / heliquest.ipmc.cnrs.fr/) (accessed on: 12 July 2020) and the result demonstrated that Brevinin-1RL1 adopted an $\alpha$-helix structure with a hydrophobic face consisting of I, A, F, I, L, A, C, F and A (Figure 1c).

Table 1. Amino acid sequence, length, molecular weight and related biological parameters of Brevinin-1RL1.

\begin{tabular}{ccccccc}
\hline Peptide & Sequence & Length (a.a) & MW (Da) & Net Charge & pI & $\begin{array}{c}\text { Hydropho- } \\
\text { bicity (H) }\end{array}$ \\
\hline $\begin{array}{c}\text { Brevinin- } \\
\text { 1RL1 }\end{array}$ & $\begin{array}{c}\text { FFPLIAGLA- } \\
\text { ARFLPKI- } \\
\text { FCSITKRC }\end{array}$ & 24 & 2711.3 & 4 & 10.11 & 0.805 \\
\hline
\end{tabular}

Notes: Molecular weight and isoelectric point (pI) of Brevinin-1RL1 were calculated by http://web.expasy (accessed on: 18 December 2019). Org/computer/. The mean Hydrophobicity (H) and Freq Polar of Brevinin-1RL1 were estimated by http://heliquest.ipmc.cnrs.fr/ (accessed on: 12 July 2020). 


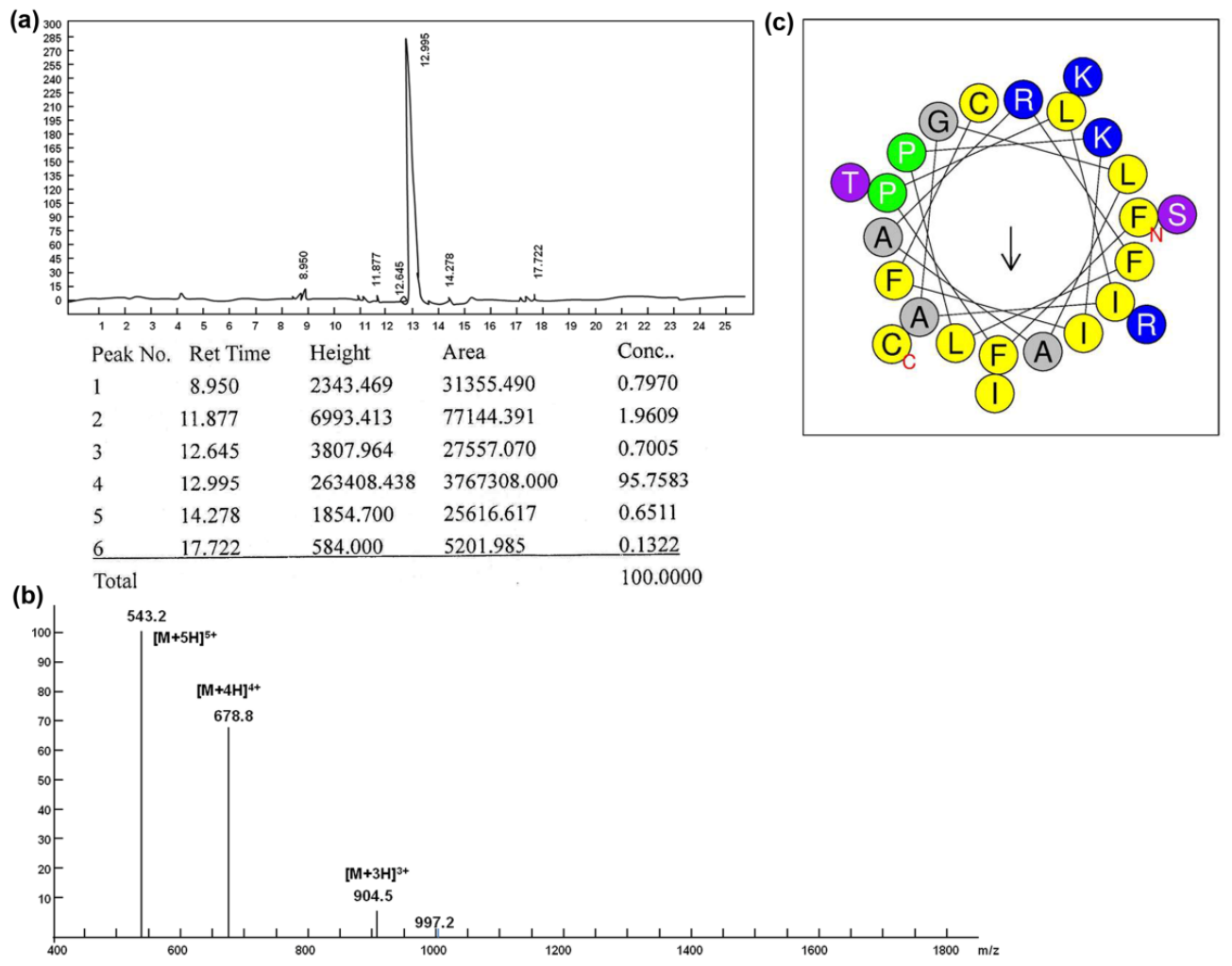

Figure 1. The purity, mass spectrometry and structure of Brevinin-1RL1. (a) The HPLC chromatogram of Brevinin-1RL1. (b) The mass spectrometry (MS) of Brevinin-1RL1. (c) Helical wheel projection of Brevinin-1RL1. The helical wheel arrangement of Brevinin-1RL1 was produced using the HeliQuest website (http:/ / heliquest.ipmc.cnrs.fr/) (accessed on: 12 July 2020). The red $\mathrm{N}$ represents the $\mathrm{N}$-terminal of the peptide sequence. The red $\mathrm{C}$ represents the C-terminal of the peptide sequence. Arrow indicates direction of the hydrophobic moment.

\subsection{Brevinin-1RL1 Displays Cytotoxicity towards Tumor Cells with Moderate Hemolysis}

To explore the antitumor activity and selectivity profile of Brevinin-1RL1, cell viability assay was conducted in six human cancer cell lines and three noncancer cell lines by 3-(4,5-dimethylthiazol-2-yl)-5-(3-carboxymethoxyphenyl)-2-(4-sulfophenyl)-2Htetrazolium (MTS) assay. As shown in Figure 2a and Table 2, Brevinin-1RL1 showed a dose-dependent inhibitory effect on various tumor cell lines (HCT116, MDA-MB-231, SW480, A549, SMMC-7721, B16-F10) with the $\mathrm{IC}_{50}$ values ranging from 5 to $10 \mu \mathrm{M}$ (Table 2). Of note, it was less toxic to noncancer cell lines, including human noncancer colonic epithelial cell line NCM460, human noncancer bronchus epithelial cell line BEAS-2B and human keratinocyte cell line $\mathrm{HaCaT}$, especially in the human keratinocyte cell line $\mathrm{HaCaT}$ $(28.67 \mu \mathrm{M})$ (Figure $2 \mathrm{~b})$. The toxicity of Brevinin-1RL1 toward cancer cells was generally about 3 times higher than toward the noncancer cell lines, indicating Brevinin-1RL1 preferentially suppressed cancer cell lines.

The Rana-box disulfide motif is a unique structure and mainly found in antimicrobial peptides from frogs, which might contribute to the functional activity of antimicrobial peptides [25]. Here, we explored the proliferation inhibitory activity of Brevinin-1RL1 with the disulfide reduced (Brevinin-1RL1 $1_{\text {red }}$ ). As shown in Figure $2 c$, the antitumor activity the peptide was deprived when the "Rana box" structure was removed. The result indicated that the structure of "Rana box" might be essential for maintaining the biological potency of Brevinin-1RL1. Furthermore, no serious hemolysis was detected in the human erythrocytes treated with Brevinin-1RL1 at the $\mathrm{IC}_{50}$ of cancer cells and only about $30 \%$ hemolysis was observed at 4-6-fold higher concentrations than $\mathrm{IC}_{50}$ (Figure 2d). These results suggested that Brevinin-1RL1 had a certainly selectivity to tumor cells and its hemolytic activity was low at the effective concentration. 

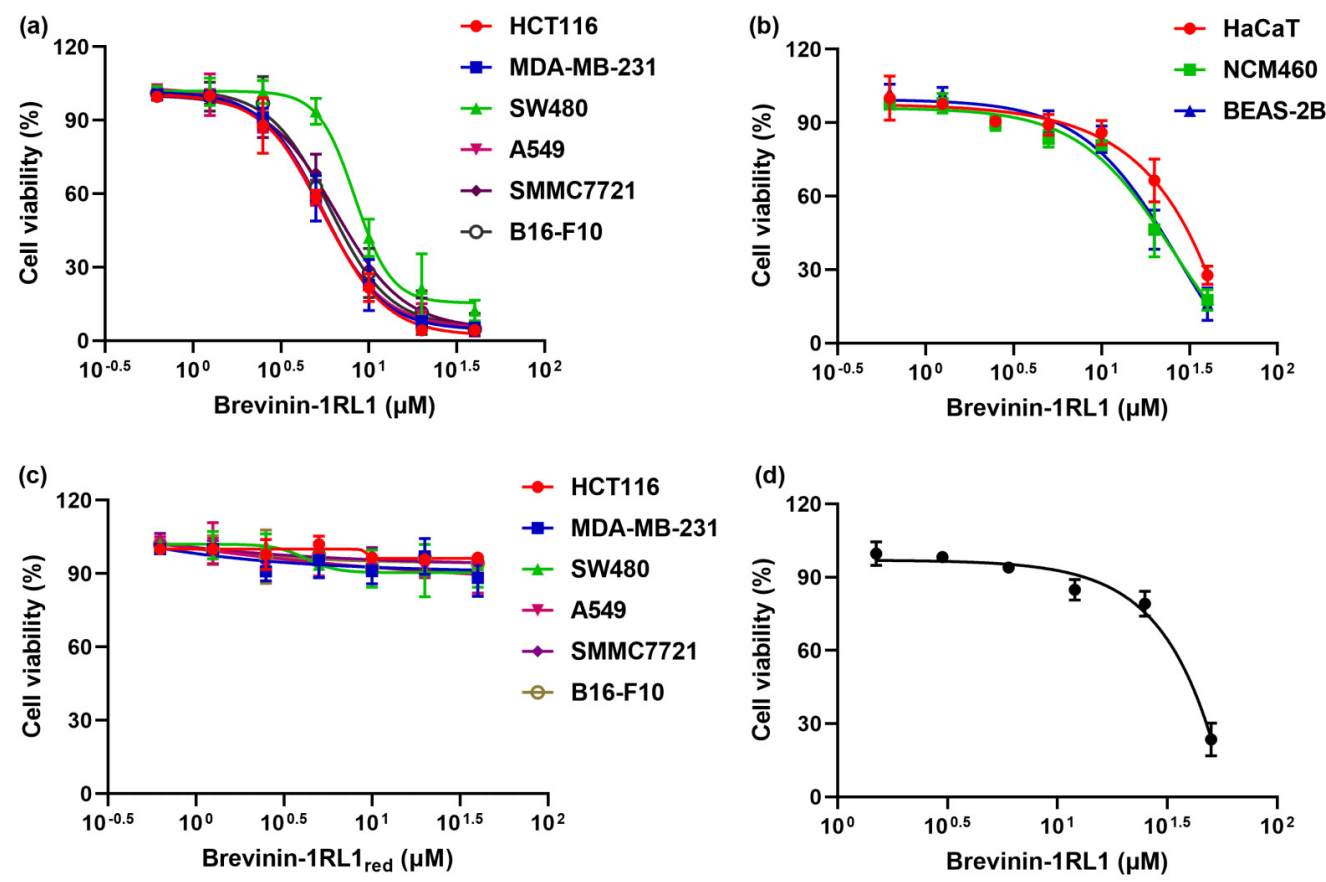

Figure 2. Brevinin-1RL1 preferentially suppressed cancer cells. The cell viability of Brevinin-1RL1 on different tumor cell lines (HCT116, MDA-MB-231, SW480, A549, SMMC7721, B16-F10) (a) and three non-tumor cell lines (HaCaT, NCM460 and BEAS-2B) (b) were determined by MTS assay. Tumor cells seeded in 96-well plates were incubated with various concentrations of Brevinin-1RL1 for $48 \mathrm{~h}$ and the cell viability was measured by MTS. (c) The cell viability of tumor cell lines treated with various concentrations of Brevinin-1RL1 $1_{\text {red }}$ was measured. (d) The erythrocyte viability of Brevinin-1RL1 on human erythrocytes was detected by hemolytic activity. Equal volume of Brevinin-1RL1 and human erythrocytes were incubated for $30 \mathrm{~min}$, the absorbance of the supernatant was measured at $540 \mathrm{~nm}$. Each experimental data is three independent experiments.

Table 2. The $\mathrm{IC}_{50}$ of Brevinin-1RL1 against different cells.

\begin{tabular}{cccc}
\hline Cell Type Caption & Cell Lines & Tumor Type & IC $_{\mathbf{5 0}}(\mathbf{M e a n} \pm \mathbf{S D}, \boldsymbol{\mu M})$ \\
\hline & HCT116 & colorectal adenocarcinoma & $5.87 \pm 0.15$ \\
& MDA-MB-231 & breast adenocarcinoma & $5.44 \pm 0.33$ \\
Tumor cells & SW480 & colorectal adenocarcinoma & $10.37 \pm 0.40$ \\
& A549 & lung adenocarcinoma & $5.81 \pm 0.23$ \\
SMMC-7721 & hepatocellular carcinoma & $6.87 \pm 0.51$ \\
Immortalized noncancer cells & B16-F10 & melanomas & $6.65 \pm 0.33$ \\
& NCM460 & colon mucosal epithelial & $16.84 \pm 0.56$ \\
& BEAS-2B & bronchial epithelial & $16.57 \pm 0.29$ \\
\hline
\end{tabular}

\subsection{Brevinin-1RL1 Induces Cell Apoptosis and Necrosis}

Brevinin-1RL1 preferential inhibited the proliferation of cancer cells, while the mechanism stayed unclear. Thus, the mechanism Brevinin-1RL1 induced proliferation was further explored. To begin with, the cell morphology changes of cells exposed to Brevinin-1RL1 or equivalent solvent (as control) were observed using optical microscope. As shown in Figure 3a, Brevinin-1RL1 treatment not only reduced the density of HCT116 and A549 in a dose-dependent manner, but also changed the tumor cells' shape. After treated with Brevinin-1RL1 at $6 \mu \mathrm{M}$, some cells displayed cell shrinkage, the sign of apoptosis. In addition, when the cells were incubated with $12 \mu \mathrm{M}$ Brevinin-1RL1 within $24 \mathrm{~h}$, a large amount of vacuolation occurred and cell debris appeared in the cell supernatant, indicating the occurrence of necrosis. Therefore, we hypothesized that Brevinin-1RL1 inhibition of tumor cells growth may be involved in both apoptosis and necrosis. 

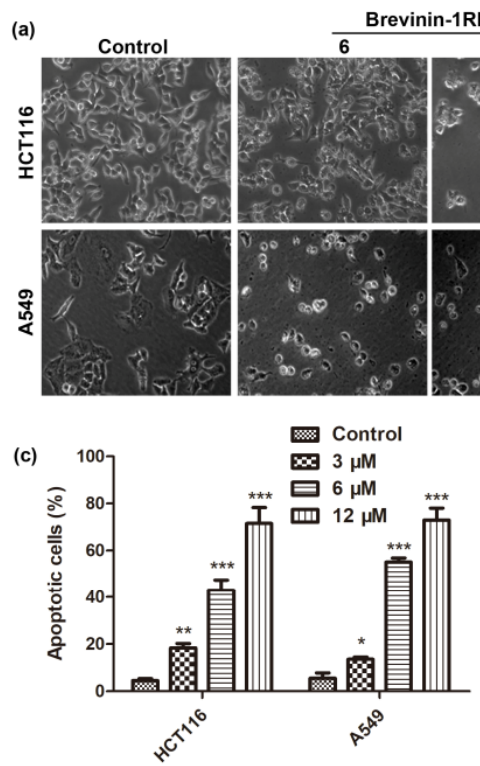

(e)

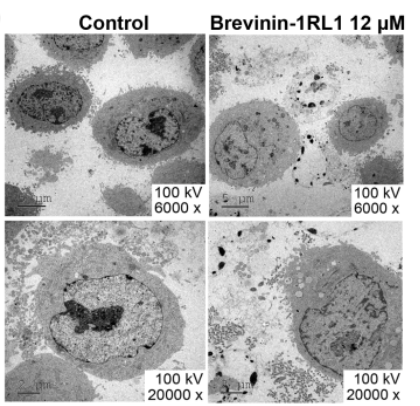

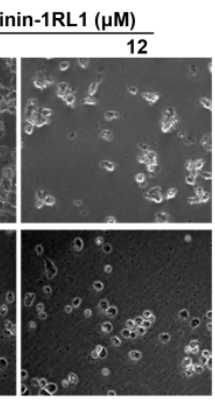
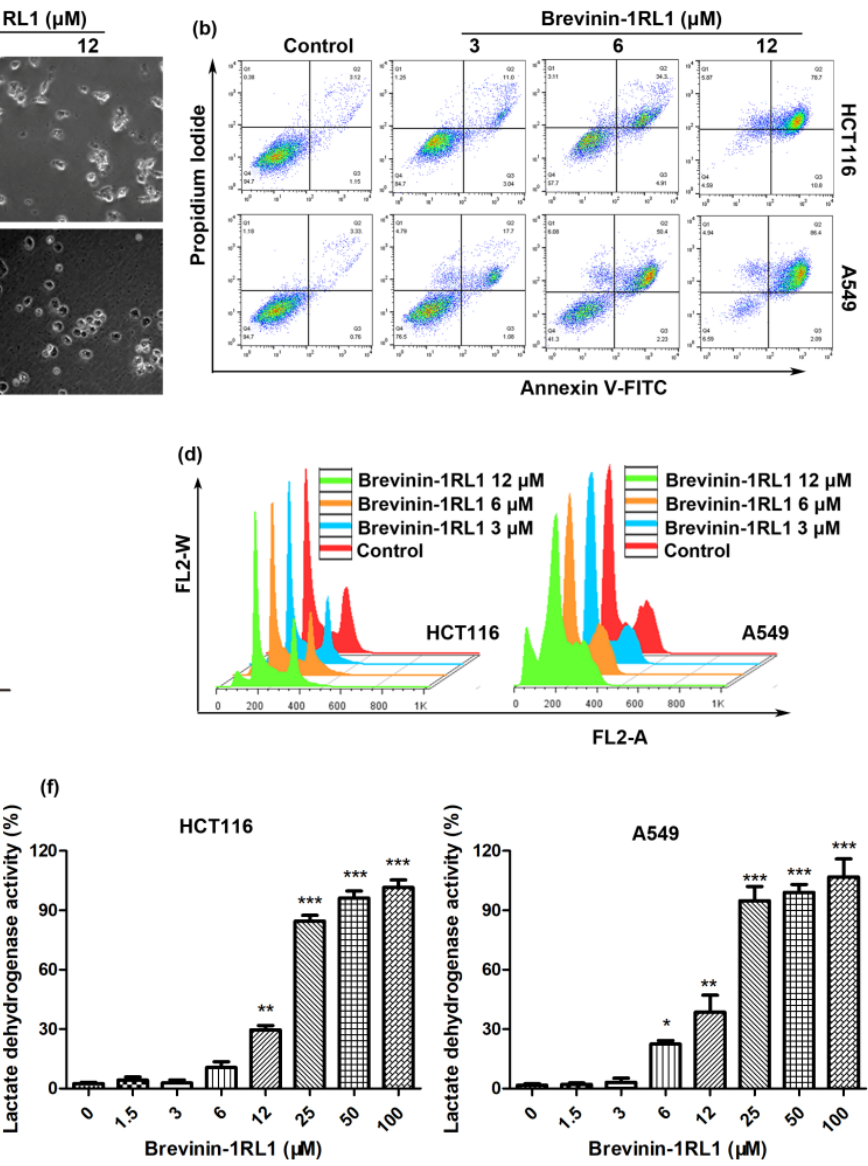

Figure 3. Brevinin-1RL1 induced cell apoptosis and necrosis in A549 and HCT116 cells. (a) The effect of Brevinin-1RL1 on morphological alteration of the tumor cell lines HCT116 and A549 cells was observed with Olympus microscope (Olympus Optical Co., Melville, NY). (b) Brevinin-1RL1 dose-dependently induced apoptosis of tumor cells. HCT116 and A549 cells were seeded in 6-well plates and co-incubated with different concentrations of Brevinin-1RL1 for $48 \mathrm{~h}$. Apoptosis was then detected by flow cytometry using Annexin-V and PI double staining. (c) The apoptotic percentage of cells was statistically analyzed. (d) The distribution of cell cycle was detected by flow cytometry in Brevinin-1RL1 treated cells. HCT116 and A549 cells inoculated in 6-well plates were treated with indicated concentrations of Brevinin-1RL1 or control for $24 \mathrm{~h}$. The cells were collected for propidium iodide (PI) staining and the cell cycle distribution was detected by flow cytometry. (e) Brevinin-1RL1 induced morphological hallmarks of cell necrosis. HCT116 cells were incubated for $12 \mathrm{~h}$ with and without Brevinin-1RL1 and the specific morphology of the cells was observed by TEM. (f) Brevinin-1RL1 induced the release of LDH in tumor cells. A549 and HCT116 cells were seeded in 96-well plates with $5 \times 10^{3}$ cells/well/100 $\mu \mathrm{L}$ and incubated with different concentrations of Brevinin-1RL1 for $24 \mathrm{~h}$. Cytoplasmic LDH release of cells was determined by the microplate reader. Each experimental data is three independent experiments. ${ }^{*} p<0.05,{ }^{* *} p<0.01,{ }^{* *} p<0.001$ in comparison to negative controls, and indicated the significant difference between the two groups. Data expressed as the mean $\pm \operatorname{SD}(n=3)$.

Cell apoptosis is the predominant cell death type, then an Annexin V-fluorescein isothiocyanate (FITC) and Propidium Iodide (PI) double staining assay was undertaken to explore whether Brevinin-1RL1 induced cell apoptosis contributed to the proliferation inhibition. As shown in Figure 3b, an increased percentage of late apoptotic cells (Annexin $\mathrm{V}+/ \mathrm{PI}+$ ) were observed in a dose-dependent manner and cell necrosis (PI+) was also detected in cells treated with Brevinin-1RL1. The apoptotic percentages of A549 and HCT116 cells were statistically analyzed as Figure 3c. Moreover, Brevinin-1RL1 resulted in accumulation of HCT116 and A549 cells in the sub-G1 phase representative of apoptotic cells in the PI single staining assay, which further confirmed Brevinin-1RL1 induced apoptosis to inhibit tumor growth. In addition, slight G0/G1-phase arrest was also detected.

Cell necrosis triggers swelling of cell mitochondria, followed by rupture of the plasma membrane and release of the cytoplasmic contents [26,27]. As shown in Figure 3e, com- 
pared with the control group, there were no typical autophagosome structures and acidic vesicles detected in Brevinin-1RL1 treated HCT116 cells, indicating Brevinin-1RL1 induced cell death was autophagy independent, while a large number of vacuoles, cell rupture and release of cytoplasmic contents were all observed in Brevinin-1RL1 treated HCT116 cells with transmission electron microscopy (TEM), which are typical characteristics of cell necrosis. In addition, Brevinin-1RL1 induced cell necrosis was further confirmed by detecting the release of lactate dehydrogenase (LDH) (Figure 3f), a stable cytosolic enzyme released into the cellular environment upon the cell membrane damaged, indicating that Brevinin-1RL1 induced necrosis at high concentrations.

\subsection{Brevinin-1RL1-Induced Cancer Cells Apoptosis Is Caspase-Dependent}

Caspases are crucial mediators of apoptosis and regulate extrinsic and intrinsic apoptotic pathways according to the caspases involved. The extrinsic induces the cleavage of caspase 8 , while the intrinsic pathway activates caspase 9, leading to the subsequent activation of caspase 3 and poly (ADP-ribose) polymerase (PARP) to induce apoptosis. To verify whether both of the pathways are involved in Brevinin-1RL1 induced apoptosis, the cleavages of caspases were detected. As shown in Figure 4a,b, both the extrinsic apoptosis indicator caspase 8 and the intrinsic caspase 9 were cleaved to activate caspase 3 and PARP. The activation of caspases leads to loss of mitochondrial membrane potential (MMP) [28,29]; thus, the MMP was assessed by the dual-emission potential-sensitive probe JC-1 dye. In intact cells, the JC-1 dye aggregates in the mitochondria and emits red fluorescence, while the dye remains monomers in the cytoplasm and exhibits green fluoresces in apoptotic cells. As shown in Figure 4c,d, Brevinin-1RL1 treatment induced aggregation of monomers, indicating the loss of MMP. These results suggested both the caspases mediating extrinsic and mitochondria intrinsic pathways were activated in Brevinin-1RL1 induced apoptosis. To confirm that Brevinin-1RL1 induced proliferation inhibitory activity is caspase dependent, the cell viabilities of HCT116 and A549 cells treated with Brevinin-1RL1 were measured in the absence or presence of the pan-caspase inhibitor z-VAD-FMK with cell viability assay. Figure 4e showed that z-VAD-FMK effectively rescued Brevinin-1RL1 induced proliferation inhibitory activity, indicating Brevinin-1RL1 induced apoptosis is, at least in part, dependent on caspases mediated extrinsic and mitochondria intrinsic pathways.

\subsection{Brevinin-1RL1 Aggregates on the Surface of Tumor Cells}

In order to investigate the preliminary antitumor mechanism of Brevinin-1RL1, the intracellular localization and binding specificity of Brevinin-1RL1 were conducted with FITC-labeled Brevinin-1RL1. As shown in Figure 5a,b, compared with non-tumor cells NCM460 and BEAS-2B, FITC-labeled Brevinin-1RL1 (FITC-B-1RL1) preferential aggregated on the surface of HCT116 and A549 cells. Meanwhile, to further confirm the affinity of Brevinin-1RL1 to tumor cells, the distribution of FITC-labeled Brevinin-1RL1 on cell surface was also evaluated with flow cytometry and cell surficial accumulation of FITC fluorescence was observed in HCT116 and A549 cells. Moreover, the parallel experimental results demonstrated less surficial FITC-labeled Brevinin-1RL1 was observed in Brevinin1RL1 insensitive noncancer cell lines NCM460 and Beas-2B, indicating Brevinin-1RL1 preferential targeted cancer cells rather than noncancer cells (Figure $5 \mathrm{c}-\mathrm{f}$ ). Aforementioned data suggested that Brevinin-1RL1 might interact with the lipids or particular proteins on the plasma membrane, further inducing apoptosis and necrosis to suppress tumor cells. 

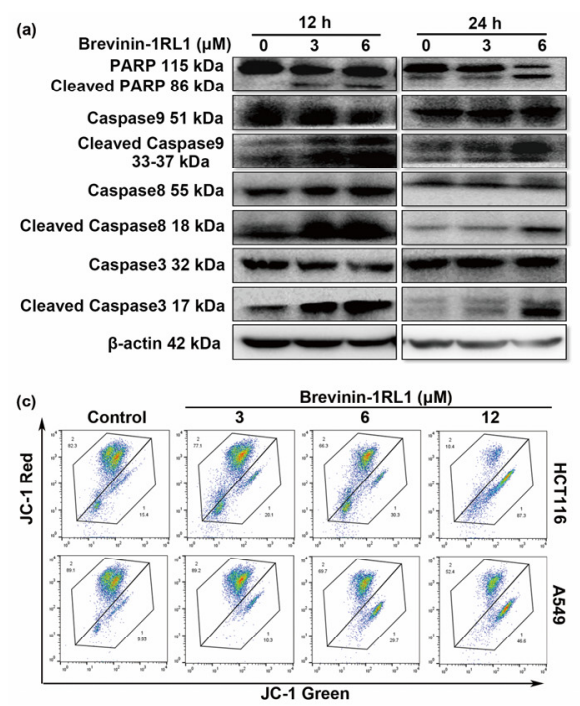

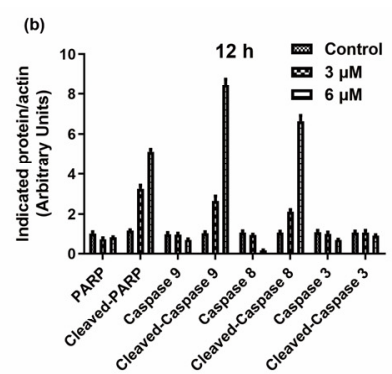

(d)

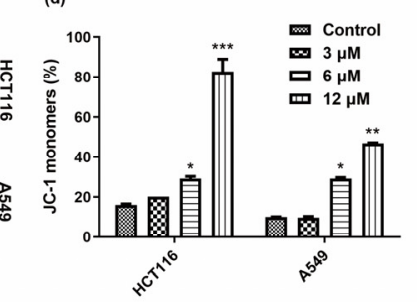

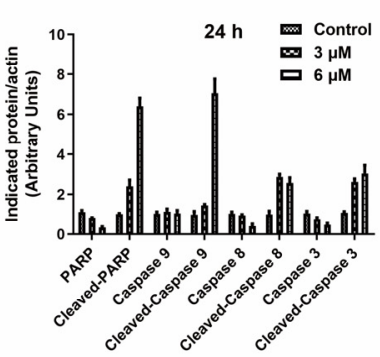

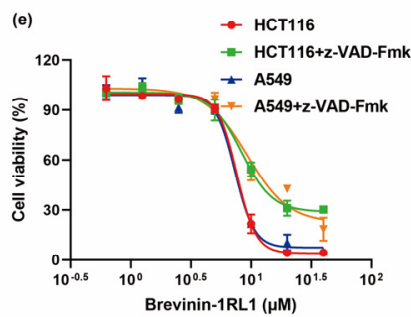

Figure 4. Brevinin-1RL1 induced cell apoptosis is caspase dependent. (a) HCT116 cells were incubated with Brevinin-1RL1 for $12 \mathrm{~h}$ or $24 \mathrm{~h}$. Cell lysis extracts were analyzed by immunoblotting to detect the cleaved activation of caspase (caspase 3, 8 , 9) and its substrates PARP. (b) Software Image J 1.52v (National Institutes of Health, Bethesda, USA) was used to analyze the gray value of caspase family proteins. (c) Effect of Brevinin-1RL1 on mitochondrial membrane potential. HCT116 and A549 cells were treated with different concentrations of Brevinin-1RL1 for $24 \mathrm{~h}$ and subjected to JC-1 stain dye and flow cytometry analysis. When the mitochondrial membrane potential is high, JC-1 aggregates in the matrix of mitochondria to form polymer and shows red fluorescence. However, when the mitochondrial membrane potential is low, JC-1 cannot aggregate in the matrix of mitochondria. At this point, JC-1 is a monomer and shows green fluorescence. The gating of the population was determined according to the change of fluorescence. (d) Quantification of the amount of JC-1 monomers and JC-1 aggregates for (c). (e) The rescuing effect of pan-caspase inhibitor z-VAD-Fmk on Brevinin-1RL1-induced cell death. Cells were preincubated with pan-caspase inhibitor $\mathrm{z}$-VAD-Fmk for $2 \mathrm{~h}$, followed by different concentrations of Brevinin-1RL1 treated for $48 \mathrm{~h}$. The cell viability of cells was determined by MTS assay. ${ }^{*} p<0.05,{ }^{* *} p<0.01$ and ${ }^{* * *} p<0.001$ in comparison to negative controls, and indicated the significant difference between the two groups for indicated comparison. Data expressed as the mean $\pm \mathrm{SD}(n=3)$.
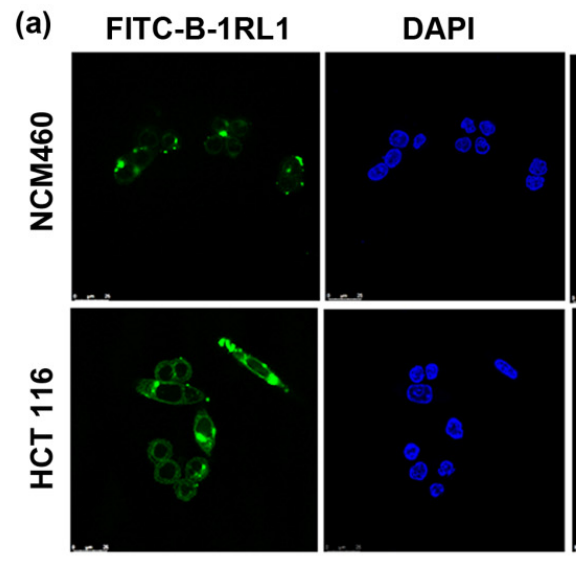
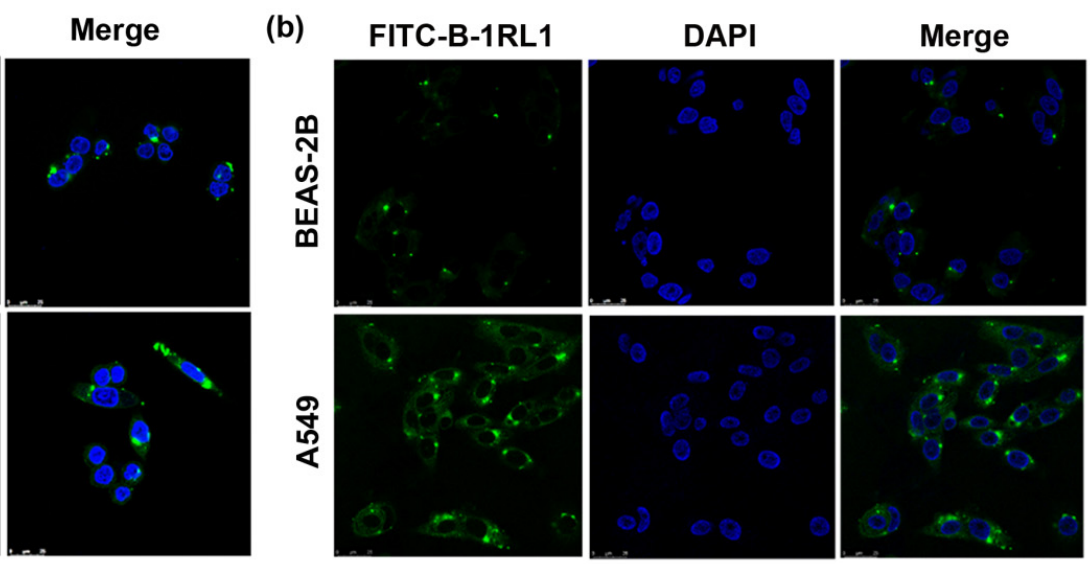

Figure 5. Cont. 
(c)

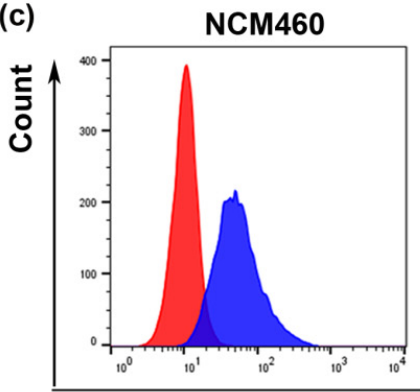

(d)

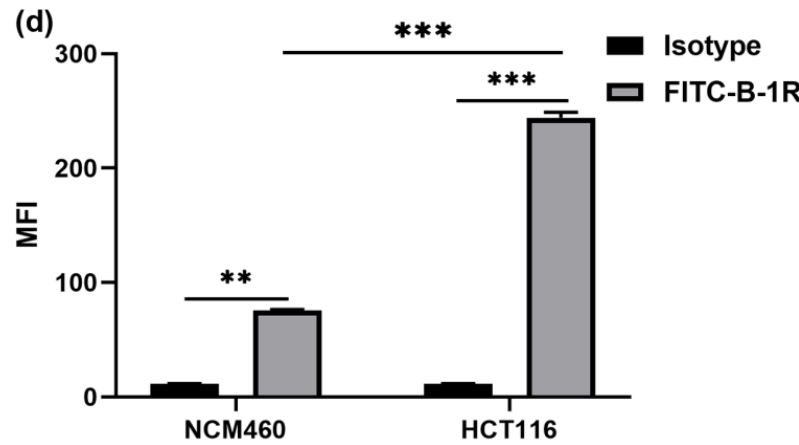

(e)
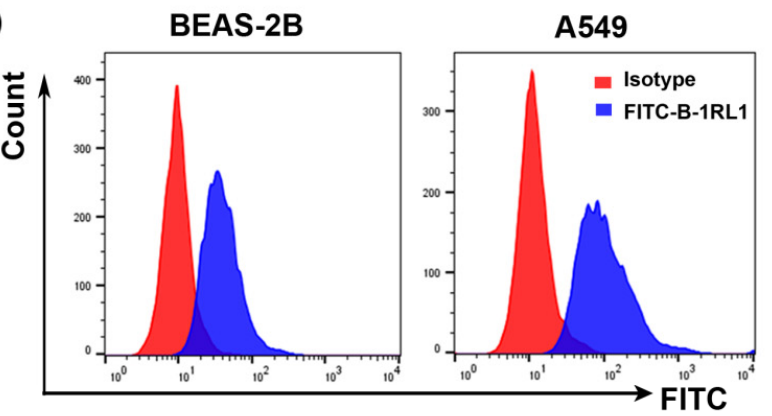

(f)

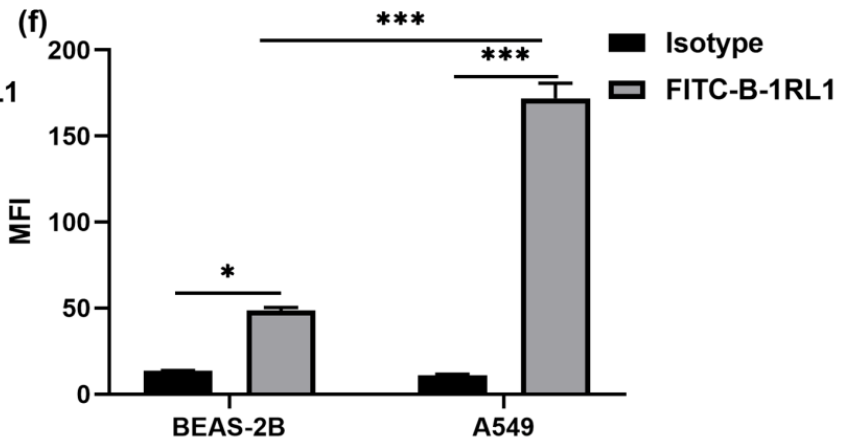

Figure 5. Brevinin-1RL1 localization and binding affinity in tumor cells. Location of Brevinin-1RL1 in NCM460 and HCT116 cells (a), BEAS-2B and A549 cells (b). Cells were seeded on glass-bottom 6-well plates and treated with FITC-labeled Brevinin-1RL1 for $12 \mathrm{~h}$. Then, the FITC-B-1RL1 was traced and recorded using laser scanning confocal microscopy. (c) The binding affinity of Brevinin-1RL1 in NCM460 and HCT116 cells (c), BEAS-2B and A549 cells (e). $1 \times 10^{6} / \mathrm{mL}$ HCT116, NCM460, A549 and BEAS-2B cells were collected and incubated with FITC-B-1RL1 or an equal dose of FITC Isotype as controlin the dark for $1 \mathrm{~h}$. Fluorescence alteration was detected by flow cytometry. (d) The MFI (Median Fluorescence Intensity) value was statistics from (c). (f) The MFI value was statistics from (e). ${ }^{*} p<0.05,{ }^{* *} p<0.01$ and ${ }^{* * *} p<0.001$ in comparison to negative controls (Isotype), and indicated the significant difference between the two groups. Data expressed as the mean $\pm \mathrm{SD}(n=3)$.

\section{Discussion}

The host defense peptides derived from frog skin secretions are bioactive products with potential antitumor therapeutic activity $[8,25,30,31]$. In the present study, we described the discovery of an AMP Brevinin-1RL1, which exhibited growth inhibitory effect towards different human tumor cells, detected with the $\mathrm{IC}_{50}$ ranging from 5 to $10 \mu \mathrm{M}$ (Figure 2a). The "Rana box" is a unique structure of peptides and contains an intermolecular disulphide bridge at the C-terminal consisting of seven to nine amino acid residues [32]. Many of these peptides originate from frogs in the Rana genus and examples include Brevinins [33], Esculentins [34], Ranatuerins [35], Ranalexins [36], Gaegurins [37], Nigrocins [38] and Ranacyclins [39]. According to previous studies, the roles of the 'Rana box' to the bioactivities of these peptides are controversial [40]. Some studies emphasized the importance of this structure since removing the "Rana box" structure from the peptide greatly reduces the antimicrobial and anti-proliferative activity [41-43]. One of the most typical examples for this family of peptides was Brevinin. Neither truncating the C-terminal cyclic nor removin g the "Rana box" structure of Brevinin-1GHa showed lower antimicrobial activity, which may explained by the shorter alpha-helix length of peptide after the removal of the C-terminal cyclic [42]. However, other studies dismissed its role as deletion of disulfide bond or truncating the "Rana box" structure showed no effect on antimicrobial activity, even reducing hemolysis [44-46]. Brevinin-1RL1 is an AMP originally isolated from Rana limnocharis composed of 24 amino acids with an intra-molecular disulfide-bridged domain of 7-membered ring located at the C-terminus and the antitumor activity was lost while the disulfide bridge was reduced, indicating the "Rana box" contributed to the bioactivity of Brevinin-1RL1 (Figure 2c). However, whether the "Rana box" of Brevinin-1RL1 involved in the formation $\alpha$ helix structure needs further investigation. 
The mechanism of AMPs inhibiting tumor cells is similar to the antimicrobial mechanism but more complicated $[12,23]$. Membrane lysis is recognized as the consistent mechanism of action between the two $[13,14,18,26]$. AMPs obtained by natural selection are cationic [47], while the tumor cells have a higher content of anionic phosphatidylserine (PS) and phosphatidylinositol (PI) on their outer leaflets distinguished from noncancer cells [48-50]. Thus, AMPs preferentially bind and insert into negatively charged cell membranes specifically by electrostatic attraction to suppress cancers selectively [49]. The typical one is the insect-derived cecropin AMPs, which combine the positive charge on the amphiphilic $\alpha$-helix with the negative charge on the cell membrane phospholipid molecule and then insert into the cell membrane to cause the loss of cell osmotic pressure and death [13]. In the cell viability assay, Brevinin-1RL1 specifically attenuated the growth of cancer cells, while less cytotoxicity against the immortalized noncancer human cells was observed (Figure 2b). Further cellular localization and binding affinity conducted with FITC-labeled Brevinin-1RL1 confirmed Brevinin-1RL1 preferred aggregated on the surface of cancer cells and exerted anticancer activity (Figure 5a-f).

Apoptosis is generally regulated by caspases and involves intrinsic mitochondrial pathways and extrinsic death receptor transduction pathways [51]. We showed that Brevinin1RL1 effectively induced apoptosis in Annexin V+/PI+ double staining (Figure 3a-c) and PI single staining assays (Figure $3 \mathrm{~d}$ ). In addition, both the death receptor pathway and the mitochondrial pathway are involved in Brevinin-1RL1 induced apoptosis, because Brevinin-1RL1 induced the activation of initiator caspase 8 and 9 (Figure $4 a, b$ ). The involvement of mitochondrial pathway was further confirmed by loss of mitochondrial membrane potential (Figure 4c,d). Moreover, the involvement of caspases in Brevinin-1RL1-induced cell death was verified by using the pan-caspase inhibitor z-VAD-FMK (Figure 3e). In addition, the release of cell contents and LDH (Figure $3 \mathrm{e}, \mathrm{f}$ ) indicated necrosis was also involved in the cytotoxicity of Brevinin-1RL1 to tumor cells. These results demonstrate that Brevinin-1RL1 induced necrosis and caspase-dependent apoptosis.

In conclusion, our study indicated that the natural derived AMP Brevinin-1RL1 is a potential candidate anticancer agent preferential acted on tumor cells to trigger necrosis and caspase-dependent apoptosis, while the specific target and the therapeutic efficacy on preclinical cancer models still need to be further investigated. Taken together, these findings provided strong evidence to demonstrate that AMP database is an effective resource to develop new cancer therapeutics.

\section{Materials and Methods}

\subsection{Peptide Synthesis}

Brevinin-1RL1 (FFPLIAGLAARFLPKIFCSITKRC, M=2711.3 g/mol) and a fluorescent dye fluorescein isothiocyanate (FITC) labeled Brevinin-1RL1 (FITC-FFPLIAGLAARFLPKIFCSITKRC, $\mathrm{M}=3213.9 \mathrm{~g} / \mathrm{mol}$ ) with an intramolecular disulfide bridge was synthesized by GL Biochem Ltd (Shanghai, China). Purification of the peptides was performed by reversed-phase HPLC (RP-HPLC) on a Vydac 218TP 510 C18 column with a linear gradient of acetonitrile in $0.1 \%$ TFA in water at a flow rate of $2 \mathrm{~mL} / \mathrm{min}$. Identity of the peptides was confirmed by MALDI-TOF mass spectrometry and protein sequencing. The purity of the synthetic peptides was higher than $95 \%$. The peptide concentrations of the non-labeled peptides were determined via measurement of UV-absorbance of tryptophan at $280 \mathrm{~nm}$ (using NanoDrop ND 1000 (Peqlab, VWR International, Inc. Erlangen, Germany)). The peptide and FITC-labeled peptide were dissolved in DMSO to prepare a stock solution $(1 \mathrm{mM})$, stored at $-20{ }^{\circ} \mathrm{C}$.

\subsection{Cell Culture}

Human non-small cell lung adenocarcinoma cell line A549, human breast adenocarcinoma cell line MDA-MB-231, human hepatocellular carcinoma cell line SMMC-7721, melanomas cell line B16-F10 and human colorectal adenocarcinoma cell lines HCT116 and SW480 were purchased from Cell Bank of Type Culture Collection of Chinese Academy of 
Sciences (Shanghai, China). The human normal colon mucosal epithelial cell line NCM460, human bronchial epithelial cell line BEAS-2B and immortalized human keratinocyte cell line $\mathrm{HaCaT}$ were purchased from the Shanghai Institute of Biochemistry and Cell Biology, Chinese Academy of Sciences (Shanghai, China). B16-F10, MDA-MB-231,BEAS-2B, SW480 and $\mathrm{HaCaT}$ cells were cultured in Dulbecco's modified Eagle medium (DMEM; Mediatech, Herndon, VA, USA) and A549, SMMC-7721, HCT116 and NCM460 cells were sustained in RPMI-1640 medium (Mediatech, Herndon, VA, USA), supplemented with $10 \%$ fetal bovine serum (FBS; Atlanta Biologicals, Lawrenceville, GA, USA), $100 \mu \mathrm{g} / \mathrm{mL}$ streptomycin (HyClone, Logan, UT, USA) and $100 \mathrm{U} / \mathrm{mL}$ penicillin (HyClone, Logan, UT, USA) in a humidified atmosphere with $5 \% \mathrm{CO}_{2}$ according to suppliers' instructions. All the cells were maintained in a humidified $5 \% \mathrm{CO}_{2}$ incubator at $37^{\circ} \mathrm{C}$ as previously described [52].

\subsection{Cell Proliferation and Viability Assay}

Anticancer activity of Brevinin-1RL1 was determined by MTS (3-(4,5-dimethylthiazol2-yl)-5-(3-carboxymethoxyphenyl)-2-(4-sulfophenyl)-2H-tetrazolium, inner salt) assay, according to the protocol of CellTiter $96^{\circledR}$ AQueous One Solution Cell Proliferation Assay kit (Promega, Madison, WI, USA). Briefly, $100 \mu \mathrm{L}$ of cell suspensions were seeded at $5 \times 10^{3}$ cells/well into each well of 96-well plates and incubate overnight before drug treatment. Then, the cells were either treated with various concentrations of peptides or without peptides for $48 \mathrm{~h}$, followed by $20 \mu \mathrm{L}$ of MTS per well. After further incubation at $37^{\circ} \mathrm{C}$ for $1-3 \mathrm{~h}$, the absorbance was determined using a Wallac 1420 Multilabel Counter (PerkinElmer Life Sciences, Wellesley, MA, USA) by measuring the optical density (OD) at $490 \mathrm{~nm}$. The half inhibitory concentration $\left(\mathrm{IC}_{50}\right)$ was determined by the relative survival curve.

\subsection{Hemolytic Activity}

To determine the toxicity of the peptides to normal mammalian cells, human erythrocytes were used to test the hemolytic activity of the peptides according to the method reported [53]. Blood was collected from the median cubital vein of healthy volunteers. The normal human erythrocytes were washed three times with Dulbecco's phosphate-buffered saline (PBS; Biological Industries, Israel), with the resulting pellet was suspended in PBS and diluted to $5 \%(w / v)$. The sample peptide was diluted with physiological saline into various gradient concentrations, $200 \mu \mathrm{L}$ of various gradient concentrations of samples and $200 \mu \mathrm{L}$ diluted red blood cells were gentle mixed and incubated at $37^{\circ} \mathrm{C}$ for $30 \mathrm{~min}$. Parallel incubations of erythrocytes in the presence of normal saline or 1\% Triton X-100 served as the negative and positive controls, respectively. After incubation, centrifugation was conducted at $2500 \mathrm{rpm} / \mathrm{min}$ for $5 \mathrm{~min}$ at room temperature. A total of $100 \mu \mathrm{L}$ of the supernatant was taken to measure the absorbance at $540 \mathrm{~nm}$ (GeneQuant, Fairfield, CT, USA). The relative optical density was compared with the absorbance of $1 \%$ Triton X-100, which induce 100\% hemolysis. The study was proved by the Research Ethics Committee of Kunming Institute of Botany, Chinese Academy of Sciences and the ethics approval number was Kib202103028. Informed consent was provided for blood donation.

\subsection{Cell Morphological Analysis}

A549 and HCT116 cells were seeded $\left(1 \times 10^{5}\right.$ cells/well $)$ in complete culture medium. The next day, the cells were treated with Brevinin-1RL1 $(0,6$ and $12 \mu \mathrm{M})$ for $24 \mathrm{~h}$, images were taken with an Olympus inverted phasecontrast microscope (Olympus Optical Co., Melville, NY, USA) (200×) equipped with the Quick Imaging system.

\subsection{Lactate Dehydrogenase (LDH)-Release Assay}

The LDH release assay was performed by the CytoTox 96 non-radioactive cytotoxicity assay kit (Promega; Charbonnie'res-les-Bains, France) according to the manufacturer's protocol as previously described [54]. Briefly, cells seeded in 96-well plates $\left(5 \times 10^{3}\right.$ cells/well $\left./ 100 \mu \mathrm{L}\right)$ were incubated with various concentrations of Brevinin-1RL1 or equivalent DMSO for $24 \mathrm{~h}$. Then, cells were lysed for $45 \mathrm{~min}$ served as the sponta- 
neous and maximum LDH activity controls for $45 \mathrm{~min}$ before running the assay. After centrifugation of the microtiter plates, $50 \mu \mathrm{L}$ of supernatant was transferred into new tube from each well and mixed with equal volume of supplied reaction mixture and incubated at $37{ }^{\circ} \mathrm{C}$ for $30 \mathrm{~min}$. A total of $50 \mu \mathrm{L}$ of supplied stop solution was added to each well and the absorbance of the colored formazan was determined using the microplate reader (Perkin-Elmer Life Sciences, Waltham, MA, USA) at $450 \mathrm{~nm}$ wavelength. Cell membrane integrity was evaluated by measuring the LDH activity released and the assay was repeated in triplicate.

\subsection{Analysis of Cell Cycle}

Cells were seeded in 6-well plates at a density of $2 \times 10^{5}$ cells/well and treated with various concentrations of the peptide for $24 \mathrm{~h}$. Cells were collected and fixed with pre-cold $70 \%$ ethanol overnight at $-20{ }^{\circ} \mathrm{C}$. After the fixation, the cells were collected and washed twice with precooled PBS, then $50 \mathrm{mg} / \mathrm{mL}$ RNase A (Sigma-Aldrich) was added for digestion at $37^{\circ} \mathrm{C}$ for $30 \mathrm{~min}$. Then, $50 \mathrm{mg} / \mathrm{mL}$ Propidium iodide (PI) was added to each sample for $15 \mathrm{~min}$ at room temperature in dark. The fluorescent intensity was evaluated by flow cytometric analysis with FACS Calibur flow cytometer (Becton Dickinson, San Jose, CA, USA).

\subsection{Analysis of Cell Apoptosis}

Cell apoptosis was analyzed by the Annexin V-FITC/PI Apoptosis kit (BD Biosciences, New Jersey, USA) according to the manufacturer's protocol. Cells were seeded in 6-well plates at a density of $1 \times 10^{5}$ cells / well and kept for $24 \mathrm{~h}$, then treated with Brevinin-1RL1 for $48 \mathrm{~h}$. Cells were collected and washed twice with cold PBS and then resuspended in $100 \mu \mathrm{L}$ of Annexin-V binding buffer, followed by incubation with Annexin V-FITC and Propidium iodide (PI) for $15 \mathrm{~min}$ at room temperature in dark. The fluorescent intensity was evaluated by flow cytometric analysis with FACS Calibur flow cytometer (Becton Dickinson, San Jose, CA, USA). Cells treated with vehicle alone (DMSO) were used as a control.

\subsection{Mitochondrial Membrane Potential}

The mitochondrial membrane potential was performed by the JC-1 Mitochondrial Membrane Potential Assay Kit (Cayman Chemical; Michigan, MI, USA) according to the manufacturer's protocol. JC-1 is an ideal fluorescent probe widely used to detect the $\triangle \Psi \mathrm{m}$ position of mitochondrial membrane electricity. Cells seeded in 6-well plates $\left(2 \times 10^{5}\right.$ cells $)$ were exposed to Brevinin-1RL1 or equivalent DMSO for $24 \mathrm{~h}$. Then, $200 \mu \mathrm{L} \mathrm{JC}-1$ staining working solution were added to each sample in the cultured cells and incubated at $37^{\circ} \mathrm{C}$ for $30 \mathrm{~min}$ in the dark. Then, collected the cells into a flow tube and analyze the fluorescence intensity with a flow cytometer.

\subsection{Immunoblotting Analysis}

Immunoblotting analysis was performed as described previously [55]. Cells were seeded in 6-well plates with a density of $3 \times 10^{5}$ cells/well and treated with or without various concentrations of Brevinin-1RL1 for $24 \mathrm{~h}$. Then, the cells were harvested and lysed in RIPA buffer (50 mM Tris- $\mathrm{HCl}$ [pH 7.4], $150 \mathrm{mM} \mathrm{NaCl}, 1 \%$ sodium deoxycholate, $0.1 \%$ sodium dodecyl sulfate, 1\% NP-40, $1 \mathrm{mM}$ EDTA and $1 \mathrm{mM}$ PMSF) that supplemented with protease inhibitors and phosphatase inhibitors (Roche). The lysate was shaken and centrifuged, the supernatant was extracted and quantified with the BCA kit (Thermo Scientific, Waltham, MA, USA) and then the loading buffer was added and boiled for $5 \mathrm{~min}$. Protein extracts were separated by denaturing SDS-PAGE and transferred to polyvinylidene fluoride (PVDF) membranes (Millipore). Membranes were blocked with 5\% non-fat milk in TBST and incubated overnight at $4{ }^{\circ} \mathrm{C}$ with the following primary antibodies: anti-Caspase9, anti-Cleaved Caspase-3 and anti-Cleaved PARP (Cell Signaling Technology, Beverly, MA, USA); anti-Caspase-3, anti-Caspase-8, anti-Cleaved Caspase- 8 and anti-Actin (Santa Cruz 
Technology, Dallas, TX, USA). The membrane was washed three times with PBST and then incubated with corresponding secondary antibody conjugated to horseradish peroxidase for $2 \mathrm{~h}$ at room temperature. Target protein band were incubated with Pierce ECL substrate and visualized by chemiluminescent detection on an ImageQuant LAS 4000 mini (GE Healthcare, Pittsburgh, Pittsburgh, PA, USA).

\subsection{Confocal Fluorescence Microscopy}

HCT116, NCM460, BEAS-2B and A549 cells were seeded and cultured in glass-bottom 6-well plates with a density of $1 \times 10^{5}$ cells/well overnight and then incubated with FITC-labeled Brevinin-1RL1 or buffer alone for $12 \mathrm{~h}$. After treatment, cells were fixed with $4 \%$ paraformaldehyde for $20 \mathrm{~min}$ and were permeabilized with $0.1 \%$ Triton X-100 for $10 \mathrm{~min}$. Then, 4', 6-diamidino-2-phenylindole (DAPI) was employed to stain the nuclei. Microscopic analysis was traced the FITC-labeled peptides with laser confocal scanning microscope.

\subsection{TEM Assay}

Briefly, A549 and HCT116 cells were seeded at a density of $5 \times 10^{4}$ cells/dish in $60 \mathrm{~mm}$ dishes. The next day, the cells were incubated with or without Brevinin-1RL1 for $24 \mathrm{~h}$. After treatment, the cells were washed twice with PBS and followed by an overnight fixation with $2 \%$ glutaraldehyde in $0.1 \mathrm{M}$ Sorensen phosphate buffer $(\mathrm{pH} 7.4)$ at $4{ }^{\circ} \mathrm{C}$ overnight. Then, the samples were washed and fixed in $1 \%$ osmium tetroxide for $1 \mathrm{~h}$ at room temperature. Samples were then dehydrated in a series of graded ethanol solutions followed by propylene oxide and cells were embedded in Epon 812 resin, which was then cut into $1 \mathrm{~mm}^{3}$ blocks. The subsequent samples were cut with ninety nanometer-thick sections and doubly contrasted with uranyl acetate and lead citrate for TEM analysis (JEOL) at an accelerating voltage of $80 \mathrm{kV}$.

\subsection{Statistical Analysis}

All statistical analyses were performed using the GraphPad PrismTM version 6.02 software from GraphPad Software Inc. (San Diego, CA, USA). In addition, the data are presented as the mean values standard deviation (SD) and statistical differences were analyzed by one-way and two-way ANOVA followed by Tuckey's post hoc test using the software package SPSS 11. The results were conducted at least three determinations for each test from three independent experiments. The statistical significance of the differences is given as ${ }^{*} p<0.05 ;{ }^{* *} p<0.01 ;{ }^{* *} p<0.001$.

Supplementary Materials: The following are available online. Figure S1: The purity and mass spectrometry and structure of FITC-labeled Brevinin-1RL1. (a) The HPLC chromatogram of FITClabeled Brevinin-1RL1. (b) The MS of FITC-labeled Brevinin-1RL1.

Author Contributions: X.J.: conceptualization, methodology, data curation, writing-review and editing; L.K.: investigation, writing-review and editing, funding acquisition; Q.Y.: resources, writing-review and editing; Y.Z., S.Z., D.F. and G.S.: investigation, resources; Y.L.: conceptualization, supervision, project administration, funding acquisition. All authors have read and agreed to the published version of the manuscript.

Funding: This research was funded by the National Natural Science Foundation of China (Nos. 81773783), the Youth Innovation Promotion Association CAS (to L.K.) and the projects of the Applied Basic Research Foundation of Yunnan Province (2018FB147).

Institutional Review Board Statement: The study was proved by the Research Ethics Committee of Kunming Institute of Botany, Chinese Academy of Sciences and the ethics approval number was Kib202103028.

Data Availability Statement: The data presented in this study, are available in this article. 
Acknowledgments: The authors are thankful to the Kunming Institute of Botany, Chinese Academy of Sciences for the support of this research. TEM investigations were performed at the Kunming Institute of Zoology, Chinese Academy of Sciences for Electron Microscopy.

Conflicts of Interest: The authors declare no conflict of interest.

Sample Availability: Samples of the compounds are available from the authors.

\section{References}

1. Repetto, L.; Comandini, D.; Mammoliti, S. Life expectancy, comorbidity and quality of life: The treatment equation in the older cancer patients. Crit. Rev. Oncol. Hemat. 2001, 37, 147-152. [CrossRef]

2. Stoletov, K.; Beatty, P.H.; Lewis, J.D. Novel therapeutic targets for cancer metastasis. Expert. Rev. Anticancer Ther. 2020, 20, 97-109. [CrossRef] [PubMed]

3. Mohan, R.; Beydoun, H.A.; Beydoun, M.A.; Barnes-Eley, M.; Davis, J.; Lance, R.; Schellhammer, P. Self-rated health as a tool for estimating health-adjusted life expectancy among patients newly diagnosed with localized prostate cancer: A preliminary study. Qual. Life Res. 2011, 20, 713-721. [CrossRef] [PubMed]

4. Luo, Y.C.; Ellis, L.Z.; Dallaglio, K.; Takeda, M.; Robinson, W.A.; Robinson, S.E.; Liu, W.M.; Lewis, K.D.; McCarter, M.D.; Gonzalez, R.; et al. Side Population Cells from Human Melanoma Tumors Reveal Diverse Mechanisms for Chemoresistance. J. Investig. Dermatol. 2012, 132, 2440-2450. [CrossRef]

5. Vymetalkova, V.; Pardini, B.; Jiraskova, K.; Urbanova, M.; Levy, M.; Veskrnova, V.; Vodicka, P.; Naccarati, A. Repeated wholeexome sequencing for cell-free tumor DNA profiling of colon cancer patients: Searching for mechanisms of acquired chemoresistance. Cancer Res. 2018, 78, 1235.

6. Hancock, R.E.W.; Diamond, G. The role of cationic antimicrobial peptides in innate host defences. Trends Microbiol. 2000, 8, 402-410. [CrossRef]

7. Wiesner, J.; Vilcinskas, A. Antimicrobial peptides: The ancient arm of the human immune system. Virulence 2010, 1, 440-464. [CrossRef]

8. Giuliani, A.; Pirri, G.; Nicoletto, S.F. Antimicrobial peptides: An overview of a promising class of therapeutics. Cent. Eur. J. Biol. 2007, 2, 1-33. [CrossRef]

9. Boman, H.G. Peptide Antibiotics and Their Role in Innate Immunity. Annu. Rev. Immunol. 1995, 13, 61-92. [CrossRef]

10. Simmaco, M.; Mignogna, G.; Barra, D. Antimicrobial peptides from amphibian skin: What do they tell us? Biopolymers 1998, 47, 435-450. [CrossRef]

11. Lazzaro, B.P.; Zasloff, M.; Rolff, J. Antimicrobial peptides: Application informed by evolution. Science 2020, 368, 487-493. [CrossRef]

12. Deslouches, B.; Di, Y.P. Antimicrobial peptides with selective antitumor mechanisms prospect for anticancer applications. Oncotarget 2017, 8, 46635-46651. [CrossRef]

13. Iwasaki, T.; Ishibashi, J.; Tanaka, H.; Sato, M.; Asaoka, A.; Taylor, D.; Yamakawa, M. Selective cancer cell cytotoxicity of enantiomeric 9-mer peptides derived from beetle defensins depends on negatively charged phosphatidylserine on the cell surface. Peptides 2009, 30, 660-668. [CrossRef]

14. Schroder-Borm, H.; Bakalova, R.; Andra, J. The NK-lysin derived peptide NK-2 preferentially kills cancer cells with increased surface levels of negatively charged phosphatidylserine. FEBS Lett. 2005, 579, 6128-6134. [CrossRef]

15. Zhang, W.; Li, J.; Liu, L.W.; Wang, K.R.; Song, J.J.; Yan, J.X.; Li, Z.Y.; Zhang, B.Z.; Wang, R. A novel analog of antimicrobial peptide Polybia-MPI, with thioamide bond substitution, exhibits increased therapeutic efficacy against cancer and diminished toxicity in mice. Peptides 2010, 31, 1832-1838. [CrossRef] [PubMed]

16. Wang, C.; Chen, T.Y.; Zhang, N.; Yang, M.J.; Li, B.; Lu, X.; Cao, X.T.; Ling, C.Q. Melittin, a Major Component of Bee Venom, Sensitizes Human Hepatocellular Carcinoma Cells to Tumor Necrosis Factor-related Apoptosis-inducing Ligand (TRAIL)induced Apoptosis by Activating CaMKII-TAK1-JNK/p38 and Inhibiting I kappa B alpha Kinase-NF kappa B. J. Biol. Chem. 2009, 284, 3804-3813. [PubMed]

17. Han, Y.F.; Cui, Z.B.; Li, Y.H.; Hsu, W.H.; Lee, B.H. In Vitro and in Vivo Anticancer Activity of Pardaxin against Proliferation and Growth of Oral Squamous Cell Carcinoma. Mar. Drugs 2016, 14, 2. [CrossRef]

18. Lehmann, J.; Retz, M.; Sidhu, S.S.; Suttmann, H.; Sell, M.; Paulsen, F.; Harder, J.; Unteregger, G.; Stockle, M. Antitumor activity of the antimicrobial peptide Magainin II against bladder cancer cell lines. Eur. Urol. 2006, 50, 141-147. [CrossRef] [PubMed]

19. Gao, S.; Hsieh, C.L.; Bhansali, M.; Kannan, A.; Shemshedini, L. A Peptide against Soluble Guanylyl Cyclase alpha 1: A New Approach to Treating Prostate Cancer. PLoS ONE 2013, 8, e64189.

20. Wang, Y.S.; Li, D.; Shi, H.S.; Wen, Y.J.; Yang, L.; Xu, N.; Chen, X.C.; Chen, X.; Chen, P.; Li, J.; et al. Intratumoral Expression of Mature Human Neutrophil Peptide-1 Mediates Antitumor Immunity in Mice. Clin Cancer Res 2009, 15, 6901-6911. [CrossRef]

21. Chen, J.G.; Xu, X.N.; Underhfll, C.B.; Yang, S.M.; Wang, L.P.; Chen, Y.X.; Hong, S.G.; Creswell, K.; Zhang, L.R. Tachyplesin activates the classic complement pathway to kill tumor cells. Cancer Res. 2005, 65, 4614-4622. [CrossRef] [PubMed]

22. Ren, S.X.; Shen, J.; Cheng, A.S.L.; Lu, L.; Chan, R.L.Y.; Li, Z.J.; Wang, X.J.; Wong, C.C.M.; Zhang, L.; Ng, S.S.M.; et al. FK-16 Derived from the Anticancer Peptide LL-37 Induces Caspase-Independent Apoptosis and Autophagic Cell Death in Colon Cancer Cells. PLoS ONE 2013, 8, e63641. [CrossRef] 
23. Xu, C.; Wang, Y.; Tu, Q.; Zhang, Z.; Chen, M.; Mwangi, J.; Li, Y.; Jin, Y.; Zhao, X.; Lai, R. Targeting surface nucleolin induces autophagy-dependent cell death in pancreatic cancer via AMPK activation. Oncogene 2019, 38, 1832-1844. [CrossRef]

24. Wang, Y.; Zhang, Y.; Lee, W.H.; Yang, X.W.; Zhang, Y. Novel Peptides from Skins of Amphibians Showed Broad-Spectrum Antimicrobial Activities. Chem. Biol. Drug Des. 2016, 87, 419-424. [CrossRef] [PubMed]

25. Jiang, Y.; Wu, Y.; Wang, T.; Chen, X.; Zhou, M.; Ma, C.; Xi, X.; Zhang, Y.; Chen, T.; Shaw, C.; et al. Brevinin-1GHd: A novel Hylarana guentheri skin secretion-derived Brevinin-1 type peptide with antimicrobial and anticancer therapeutic potential. Biosci. Rep. 2020, 40, 1-11. [CrossRef] [PubMed]

26. Wodlej, C.; Riedl, S.; Rinner, B.; Leber, R.; Drechsler, C.; Voelker, D.R.; Choi, J.Y.; Lohner, K.; Zweytick, D. Interaction of two antitumor peptides with membrane lipids - Influence of phosphatidylserine and cholesterol on specificity for melanoma cells. PLoS ONE 2019, 14, e0211187. [CrossRef] [PubMed]

27. Los, M.; Mozoluk, M.; Ferrari, D.; Stepczynska, A.; Stroh, C.; Renz, A.; Herceg, Z.; Wang, Z.Q.; Schulze-Osthoff, K. Activation and caspase-mediated inhibition of PARP: A molecular switch between fibroblast necrosis and apoptosis in death receptor signaling. Mol. Biol. Cell 2002, 13, 978-988. [CrossRef]

28. Riedl, S.; Rinner, B.; Schaider, H.; Lohner, K.; Zweytick, D. Killing of melanoma cells and their metastases by human lactoferricin derivatives requires interaction with the cancer marker phosphatidylserine. Biometals 2014, 27, 981-997. [CrossRef]

29. Green, D.; Kroemer, G. The central executioners of apoptosis: Caspases or mitochondria? Trends Cell Biol. 1998, 8, 267-271. [CrossRef]

30. Conlon, J.M.; Mechkarska, M.; Lukic, M.L.; Flatt, P.R. Potential therapeutic applications of multifunctional host-defense peptides from frog skin as anti-cancer, anti-viral, immunomodulatory, and anti-diabetic agents. Peptides 2014, 57, 67-77. [CrossRef]

31. Van Zoggel, H.; Hamma-Kourbali, Y.; Galanth, C.; Ladram, A.; Nicolas, P.; Courty, J.; Amiche, M.; Delbe, J. Antitumor and angiostatic peptides from frog skin secretions. Amino Acids 2012, 42, 385-395. [CrossRef] [PubMed]

32. Haney, E.F.; Hunter, H.N.; Matsuzaki, K.; Vogel, H.J. Solution NMR studies of amphibian antimicrobial peptides: Linking structure to function? Biochim. Biophys. Acta 2009, 1788, 1639-1655. [CrossRef]

33. Morikawa, N.; Hagiwara, K.; Nakajima, T. Brevinin-1 and -2, unique antimicrobial peptides from the skin of the frog, Rana brevipoda porsa. Biochem. Biophys. Res. Commun. 1992, 189, 184-190. [CrossRef]

34. Maurizio Simmaco, G.M. Donatella Barra and Francesco Bossa Novel antimicrobial peptides from skin secretion of the European frog Rana esculenta. FEBS Lett. 1993, 324, 159-161. [CrossRef]

35. Goraya, J.; Knoop, F.C.; Conlon, J.M. Ranatuerins antimicrobial peptides isolated from the skin of the American bullfrog, Rana catesbeiana. Biochem. Biophys. Res. Commun. 1998, 250, 589-592. [CrossRef] [PubMed]

36. Clark, D.P.; Durell, S.; Maloy, W.L.; Zasloff, M. Ranalexin. A novel antimicrobial peptide from bullfrog (Rana catesbeiana) skin, structurally related to the bacterial antibiotic, polymyxin. J. Biol. Chem. 1994, 269, 10849-10855. [CrossRef]

37. Park, J.M.; Jung, J.E.; Lee, B.J. Antimicrobial peptides from the skin of a korean frog, rana rugosa. Biochem. Biophys. Res. Commun. 1994, 205, 948-954. [CrossRef] [PubMed]

38. Park, S.H.; Ahn, H.C.; Kim, S.S.; Lee, B.J. Structural study of novel antimicrobial peptides, nigrocins, isolated from rana nigromaculata. FEBS Lett. 2001, 507, 95-100. [CrossRef]

39. Mangoni, M.L.; Papo, N.; Mignogna, G.; Andreu, D.; Shai, Y.; Barra, D. Ranacyclins, a new family of short cyclic antimicrobial peptides: Biological function, mode of action, and parameters involved in target specificity. Biochemistry 2003, 42, 14023-14035. [CrossRef]

40. Kozic, M.; Vukicevic, D.; Simunic, J.; Roncevic, T.; Antcheva, N.; Tossi, A.; Juretic, D. Predicting the Minimal Inhibitory Concentration for Antimicrobial Peptides with Rana-Box Domain. J. Chem. Inf. Model. 2015, 55, 2275-2287. [CrossRef]

41. Abraham, P.; Sundaram, A.; R, A.; V, R.; George, S.; Kumar, K.S. Structure-Activity Relationship and Mode of Action of a Frog Secreted Antibacterial Peptide B1CTcu5 Using Synthetically and Modularly Modified or Deleted (SMMD) Peptides. PLoS ONE 2015, 10, e0124210. [CrossRef] [PubMed]

42. Chen, Q.; Cheng, P.; Ma, C.; Xi, X.; Wang, L.; Zhou, M.; Bian, H.; Chen, T. Evaluating the Bioactivity of a Novel Broad-Spectrum Antimicrobial Peptide Brevinin-1GHa from the Frog Skin Secretion of Hylarana guentheri and Its Analogues. Toxins 2018, 10, 413. [CrossRef]

43. Chen, X.; Zhang, L.; Ma, C.; Zhang, Y.; Xi, X.; Wang, L.; Zhou, M.; Burrows, J.F.; Chen, T. A novel antimicrobial peptide, Ranatuerin-2PLx, showing therapeutic potential in inhibiting proliferation of cancer cells. Biosci. Rep. 2018, 38 , BSR20180710. [CrossRef]

44. Marenah, L.; Flatt, P.R.; Orr, D.F.; Shaw, C.; Abdel-Wahab, Y.H. Skin secretions of Rana saharica frogs reveal antimicrobial peptides esculentins-1 and -1B and brevinins-1E and -2EC with novel insulin releasing activity. J. Endocrinol. 2006, 188, 1-9. [CrossRef] [PubMed]

45. Won, H.S.; Kang, S.J.; Lee, B.J. Action mechanism and structural requirements of the antimicrobial peptides, gaegurins. Biochim. Biophys. Acta 2009, 1788, 1620-1629. [CrossRef]

46. Islas-Rodriguez, A.E.; Marcellini, L.; Orioni, B.; Barra, D.; Stella, L.; Mangoni, M.L. Esculentin 1-21: A linear antimicrobial peptide from frog skin with inhibitory effect on bovine mastitis-causing bacteria. J. Pept. Sci. 2009, 15, 607-614. [CrossRef] [PubMed]

47. Chiangjong, W.; Chutipongtanate, S.; Hongeng, S. Anticancer peptide: Physicochemical property, functional aspect and trend in clinical application (Review). Int. J. Oncol. 2020, 57, 678-696. [CrossRef] [PubMed] 
48. Ran, S.; Downes, A.; Thorpe, P.E. Increased exposure of anionic phospholipids on the surface of tumor blood vessels. Cancer Res. 2002, 62, 6132-6140.

49. Connor, J.; Bucana, C.; Fidler, I.J.; Schroit, A.J. Differentiation-Dependent Expression of Phosphatidylserine in Mammalian Plasma-Membranes - Quantitative Assessment of Outer-Leaflet Lipid by Prothrombinase Complex-Formation. Prac. Natl. Acad. Sci. USA 1989, 86, 3184-3188. [CrossRef]

50. Yavari, B.; Mahjub, R.; Saidijam, M.; Raigani, M.; Soleimani, M. The Potential Use of Peptides in Cancer Treatment. Curr. Protein Pept. Sci. 2018, 19, 759-770. [CrossRef]

51. Kim, R.; Emi, M.; Tanabe, K. Role of mitochondria as the gardens of cell death. Cancer Chemoth. Pharm. 2006, 57, 545-553. [CrossRef] [PubMed]

52. An, T.; Gong, Y.; Li, X.; Kong, L.; Ma, P.; Gong, L.; Zhu, H.; Yu, C.; Liu, J.; Zhou, H.; et al. USP7 inhibitor P5091 inhibits Wnt signaling and colorectal tumor growth. Biochem. Pharmacol. 2017, 131, 29-39. [CrossRef] [PubMed]

53. Minn, I.; Kim, H.S.; Kim, S.C. Antimicrobial peptides derived from pepsinogens in the stomach of the bullfrog, Rana catesbeiana. Bba-Mol. Basis Dis. 1998, 1407, 31-39. [CrossRef]

54. Liang, X.; Wang, R.; Dou, W.; Zhao, L.; Zhou, L.; Zhu, J.; Wang, K.; Yan, J. Arminin 1a-C, a novel antimicrobial peptide from ancient metazoan Hydra, shows potent antileukemia activity against drug-sensitive and drug-resistant leukemia cells. Drug Des. Dev. Ther. 2018, 12, 3691-3703. [CrossRef]

55. Zhu, H.F.; Wang, B.; Kong, L.M.; An, T.; Li, G.T.; Zhou, H.Y.; Gong, L.; Zhao, Z.X.; Gong, Y.X.; Sun, H.D.; et al. Parvifoline AA Promotes Susceptibility of Hepatocarcinoma to Natural Killer Cell-Mediated Cytolysis by Targeting Peroxiredoxin. Cell Chem. Biol. 2019, 26, 1122. [CrossRef] [PubMed] 